Article

\title{
Sustainability in the Brazilian Heavy Construction Industry: An Analysis of Organizational Practices
}

\section{Luis Roberto Arruda ${ }^{1}{ }^{1}$, Valdir de Jesus Lameira ${ }^{2}$, Osvaldo Luiz Gonçalves Quelhas ${ }^{1}$ and Fernando Neves Pereira ${ }^{3,4}$}

1 Federal Fluminense University, MSG/LATEC, Rua Passo da Pátria 156, sala 329-A - Bloco E, CEP 24210-240, Niterói - RJ, Brazil; E-Mail: quelhas@latec.uff.br; Tel.:+55-21-2629-5620

INESC Coimbra, University of Coimbra, Portugal, Rua Antero de Quental, 199, Coimbra 3000-033, Portugal; E-Mail: vlameira@uol.com.br; Tel.: +351-239-851-040; Fax: +351-239-824-692

3

Federal Center of Technological Education, Sockow Celso Fonseca, Av. Maracanã, 229 sala 01 - Bloco A, CEP 20271-110, Maracanã- RJ, Brazil; E-Mail: fnevesp@gmail.com

4 Civil Engineering, Federal Fluminense University, Rua Passo da Pátria 156, sala 329-A - Bloco E, CEP 24210-240, Niterói- RJ, Brazil

* Author to whom correspondence should be addressed; E-Mail: luisarruda@oi.com.br; Tel.:+55-21-2629-5620.

Received: 7 August 2013; in revised form: 24 September 2013 / Accepted: 26 September 2013/ Published: 30 September 2013

\begin{abstract}
This study performs a comparison between the theoretical frameworks of sustainable development and its incorporation in the decision-making practices and models used by heavy construction companies. This study was conducted by using documentary analysis of corporate sustainability reports. Specifically, the content analysis method was used to examine the sustainability reports disclosed by the companies studied. The results indicate four main conclusions: first, the social, political and economic context directed the companies towards implementing sustainable management practices; second, human resource development follows the traditional model of training and development; third, there is an evident effort to balance economic goals and profit-making with social responsibility practices as a way to characterize the corporate commitment with sustainability; fourth, effective and indispensable measures to transform decision-making models were not adopted in the business practices analyzed, and thus the economic factor continues to be prioritized at the expense of social and environmental aspects in those models. This paper, in looking at three Brazilian multinational heavy construction companies, examines the synergy between the theoretical and the identified corporate
\end{abstract}


sustainability practices. Lastly, this paper may be characterized as a descriptive study based on a literature review and an analysis of sustainability reports from the companies studied.

Keywords: corporate social responsibility; sustainable development; heavy construction; organizational practices

\section{Introduction}

Companies in the heavy construction sector build roads, ports, bridges, airports, power plants and tunnels among other things.

In 2007, the Brazilian government launched the Growth Acceleration Program (Programa de Aceleração do Crescimento - PAC) based on the conviction that public investments stimulate economic growth. Infrastructure projects form the basis of this economic growth program, thus creating a strategic mechanism for national development in terms of integrating and reducing regional and social inequalities. The social and environmental impact of large-scale projects is relevant and leads to consequences of economic losses.

Given this expansion movement, the heavy construction sector, which is responsible for infrastructure projects, has been introducing management models to reduce social risk, environmental risk and economic risk. These models use sustainability as the impetus for carrying out economically viable projects with positive social impacts and respect for the environment.

In this sense, Afonso [1] provides a relevant contribution to management, as she questions the use of the notion of sustainability in the field of business. According to Afonso [1], many companies have incorporated the concept of sustainability within their discourse without changing their decision-making and production processes.

The objective of this study is to compare the theoretical frameworks regarded as paradigms of corporate sustainability and their incorporation into the practices and decision-making models used by heavy construction companies.

This study examines the synergy between the theoretical frameworks of corporate sustainability and the practices identified in Brazilian heavy construction companies operating internationally.

\section{Literature Review}

This chapter will be divided into two topics related to sustainability aiming to support the analysis of organizational practices in the Brazilian construction industry. The studies included in our analysis, which were all conducted by academically recognized authors, support the assessments performed and contribute to the authors' conclusions.

\subsection{Sustainability: Discourse and Practices}

The literature review on sustainable development and sustainability indicates the diversity of approaches that are incorporated into corporate management systems [2-7].

Sustainability issues involve complex interactions between social, economic and environmental factors, which are often perceived quite differently by different interest groups [8]. 
Worldwide, large companies were motivated to implement sustainable development policies from 1970 to 1980 upon being pressured by the political context of the operations, social movements of environmental protection groups and changes in the competitive environment resulting from economic globalization. In the case of Brazilian companies, this movement has occurred more recently and dates back to the period between 1990 and 2000 [9].

Another important point found in the literature related to sustainability practices was the identification of two conceptual matrices that polarize the debates on sustainable development and sustainability. The first, which was on sustainable development, corresponds to the "Report on Our Common Future" [10] and holds hegemony over the issue. The discourse of this report promises to increase production while reducing the consumption of natural resources and the release of waste into the environment. The second study, which was related to sustainability, stems from eco-developmental proposals [11]. The conclusions from this study contrast with the GRI (Global Reporting Initiative) first discourse by attaching importance to the role of civil society in the transition towards sustainability, in the prioritization of social equity and in the distrust of the market's role as an allocator of resources [3,5].

One of the models addressing the motivating factors for organizational sustainability is that of Munilla and Miles [12], which indicates that Corporate Sustainability develops from one of the following reasons:

- $\quad$ Strategic, aimed at creating competitive advantage [13];

- Mere compliance, i.e. the changes must be implemented, as required by the legal framework governing the organization [13];

- $\quad$ Pressure from different social groups or stakeholders [14].

For Porter and Kramer [15], companies that respond to the call of sustainability can do so by adopting a strategic or responsive approach. What defines such approaches corresponds to the ethical involvement of the company regarding societal issues.

A responsive company attempts to have some type of community action and reduce the social and environmental damage caused by the activities of its value chain. In practice, this means that the company reacts to the demands of society by minimizing its social and environmental risks and making investments in more general causes, with clear social interest, that do not directly interfere with its operations or influence its competitiveness in the medium and long term.

In strategic sustainability, the company transforms its production chain activities to simultaneously benefit society and strengthen its business strategy. Regarding the social investment aspects, the company selects issues that contribute to improving the competitiveness of its business in some way. Based on both classifications (responsive and strategic), Porter and Kramer [15] show that the greater the relationship of social and environmental issues with the business activity of a company, the greater the chances are for the company to achieve competitive and effective success for social and environmental benefits.

A company that is aware of its role as an institution embedded in society and attentive to its expectations should be alert to the need for strategically developing sustainability in its operating environment. Thus, companies have the responsibility to practice their trade based on the principle of sustainable development. In this way, the company seeks to participate in the process of social change, 
encouraging reflections and embracing the fields of academia, civil society and government regarding the necessary economic, social and environmental transformations.

For Cheibub and Locke [16], a socially responsible company is the result of a collective enterprise and is characterized by fulfilling the rules of the democratic game while not seeking to obtain unfair or special advantages. A socially responsible company is one that is engaged in actions that reinforce democracy by strengthening the public sphere of social decision.

Social responsibility and sustainability are the new paradigms of social action. Mission, vision and values are theoretically the assumptions that serve as a company's parameters, whereas profit represents the goal of every private company. However, these variables should not be the only ones because a company also needs to meet social demands by using all of these parameters to solve social problems in a sustainable manner.

Management theories such those of Drucker [17] and Taylor [18] are not only applicable to solving business problems but are also applicable to solving societal conflicts, wherein companies must align their goals with sustainable social solutions.

Barin [19] presented a comparison of conceptual propositions and operational propositions with the business practices of companies studied in his doctoral thesis. Conceptual propositions are corporate governance, business ethics and organizational learning. Operational propositions consist of the following: governance, the structure of the area of sustainable development, profit-sharing with stakeholders, business ethics - content, goal setting and corporate attitude - and organizational learning, awareness and information sharing on sustainable development.

\subsection{Sustainability in Construction}

The "triple bottom line" is an important fundamental concept of sustainable construction that has been defined by the authors Dyllick and Hockerts [20] and Elkington [21] and emphasizes the three traditional pillars of ecological quality, economic quality and social quality.

However, regulation in construction also has different meanings for different segments of a society such as professionals working in the civil construction industry, academia, civil society and politics [22]. As an example, Wheeler and Beatley [23] work with the concept of economic, social and environmental quality in such a way that a conceptual triad for construction is composed of the following:

- In environmental quality, construction focuses on the following: renewable energy sources and use, efficient water usage, pollution with limits for $\mathrm{CO}_{2}$ emission and waste reduction during construction, improving the recycling process to reduce waste, protecting the environment and biodiversity such as fauna and flora, as well as using renewable and recyclable materials including salvaged materials from old buildings.

- In economic quality, companies can be efficient and competitive even if they promote the reduced use of the abovementioned items such as water, energy and adaptations in constructions while supporting local economic diversity. Companies should also promote quality for employees and all those directly and indirectly affected by the construction in addition to seeking a local workforce and sustainable planning for economic viability. 
- In social quality, the ethical values should be highlighted such as providing a healthy work environment, adequate services, goods in accordance with rules and regulations and respect for the local community during construction activities. All types of information, training and equipment affecting workers and local residents should be provided.

Sustainable construction initiatives have been a recurring theme; however, some construction companies are trying to overcome these market barriers by only seeking technological innovations that provide them with specific advantages for clean construction [24].

Factors such as regulatory changes and public opinion - the latter of which has an increasing interest in sustainability issues - provide greater pressure to improve sustainable performance in the construction industry. However, despite the construction industry being receptive to discussing these economic, environmental and social changes, it has an enormous reputation for being conservative with respect to change $[25,26]$.

Technologically, the construction sector changes gradually over time, and this path depends largely on the particular history of each company, which in this industry, depends on the connections between companies and familiar technologies [27].

Sustainable construction is often considered from the standpoint of a green economy in the social and environmental spheres, but a more comprehensive approach is necessary. Rather, a wider view of sustainable construction should be adopted for isolated, self-sufficient construction as well as for projects that move the entire urban system by involving businesses, citizens and the government.

However, the global perspective of sustainable development in the construction industry promotes the sustainable construction ideals of high-performance buildings, green architecture and green construction. Construction projects without sustainable features are projects that carry the name of "brown", "traditional" or "unsustainable" projects. Whatever the description given to a project, there is a general view that sustainable construction projects are well-planned and well-built with the expectation of providing high-quality and urban integration, functionality, economy and an adequate infrastructure that can respond to social, economic and environmental needs [28].

The existing construction projects cannot be forgotten within the context of sustainable construction because they already occupy part of the urban space and because they remain the largest portion of construction projects when compared with new sustainable construction projects. Corps [29] and Pivo [30] have suggested that making improvements to increase the performance of existing constructions is more important than building more sustainable constructions because the existing constructions account for the largest proportion of the resources that were spent to produce them. Thus, most assessment tasks involving aspects of sustainability will refer to constructions that were not originally sustainable.

Sustainable construction can lead to improvements within its location raising the standards of the local community to use energy, water and materials in a more appropriate way and to recycle goods and make social improvements within that region. Ellison and Sayce [31] have suggested that the contextual fit, which refers to sustainability in terms of adapting a building within its location, can have three effects: first, as a reference for positive impact on the values of its location; second, as a positive environmental effect where the building increases the values of its estate properties directly benefiting the owners; and third, there may be a negative effect when the builder impedes the social and business activity of the area with a relative impact on the areas that did not benefit from sustainable construction. 
All segments of society have the right to enjoy the ecosystem; however, everyone has a duty and responsibility to protect that ecosystem. Sustainable harmony between human life and nature is a difficult goal but is achievable when economic, social and environmental sectors unite with common goals. This type of sustainable thought is vital for the balanced future of mankind [32].

\section{Research Methods}

This study is characterized as descriptive research based on a literature review and an analysis of sustainability reports from the companies studied. This study performs a comparison of the sustainability reports with the conceptual propositions and operational propositions [19]. In the sustainability reports, the documentary analysis technique was used to identify aspects related to business models, the concepts and practices of sustainability and corporate educational actions. By comparing the content of the sustainability reports with the scientific literature, a critical analysis was developed based on the incorporation of sustainable development concepts in the practices and decision-making models used in heavy construction companies. The "filter" used in this critical analysis were the conceptual and operational propositions defined by Barin [19].

\section{Characterizing the Heavy Construction Companies Studied}

In 2008 and 2009, the Brazilian heavy construction sector had a growth trajectory driven by the acceleration of infrastructure projects by federal and state governments. The revenue of the 100 largest construction companies in 2009 according to the July 2010 issue of the magazine "O Empreiteiro" [The Contractor] were the highest earnings in a 15-year period and showed growth for the fifth consecutive year.

The selection criteria for the three companies in this study was "Companies with the highest revenues in 2009" based on the rankings published in the July 2010 issue of "O Empreiteiro". The three companies analyzed operate nationally and have an important role in heavy construction. The conclusions obtained by analyzing their sustainability actions allow the comparison of their sustainability actions with other companies in the heavy construction industry.

The sustainability reports from these companies as well as the ranking of the companies with the highest revenue are publicly available online. However, confidentiality was assured by renaming the companies Company A, Company B and Company C, as these companies did not provide authorization to use their names.

Table 1 shows the characteristics of the companies included in our study.

Table 1. Characterization of the companies.

\begin{tabular}{cccc}
\hline \multirow{2}{*}{ Categories } & \multicolumn{3}{c}{ Companies } \\
\cline { 2 - 4 } & Company A & Company B & Company C \\
\hline Gross revenue of the company (in billions) & $\mathrm{R} \$ 40.6$ & $\mathrm{R} \$ 19.0$ & $\mathrm{R} \$ 18.2$ \\
Gross revenue in the engineering sector (in billions) & $\mathrm{R} \$ 18.7$ & $\mathrm{R} \$ 6.1$ & $\mathrm{R} \$ 6.0$ \\
Number of employees & 87,662 & 47,297 & 18,293 \\
\hline
\end{tabular}

Source: 2009 Sustainability reports from the companies. 


\subsection{Study Items}

In the sustainability reports disclosed by these companies, the dimensions and categories listed in Table 2 were analyzed, which comprise the "sustainability report" model proposed by the Global Reporting Initiative (GRI) [33].

\subsection{Temporal and Geographic Boundaries of the Study}

The data gathered focused on Brazilian companies in the heavy construction sector. Sustainability reports from 2009 were used, which were all available on the corporate websites of the companies [33].

Table 2. Dimensions and categories of documentary analysis.

\begin{tabular}{clc}
\hline \multicolumn{1}{c}{ Dimension } & \multicolumn{1}{c}{ Category } & Actors and References \\
\hline & $\begin{array}{l}\text { Characteristics of the political, social and } \\
\text { competitive environment in the historical } \\
\text { Management Concepts }\end{array}$ & $\begin{array}{l}\text { context of sustainability; Political-philosophical } \\
\text { trends; Debate on sustainable development } \\
\text { and sustainability. }\end{array}$ \\
& $\begin{array}{l}\text { Economic models and environmental impacts; } \\
\text { Approach to sustainability; International } \\
\text { certification; Management indicators; Socio- } \\
\text { Business Models }\end{array}$ & $\begin{array}{c}\text { Sustainability reports disclosed } \\
\text { by the companies studied. }\end{array}$ \\
& $\begin{array}{l}\text { Economic knowledge; Intellectual capital; } \\
\text { Lower- and higher-order leaning; Skill } \\
\text { Human Resources }\end{array}$ & \\
& development. & [41-47] \\
\hline
\end{tabular}

\section{Methods}

This section displays the methods of the analysis of the sustainability reports. Researcher notes were organized into categories and Dimensions and categories of documentary analysis to search for patterns, regularities, differences and contradictions that would allow for an accurate analysis of the data.

\subsection{Business Models}

According to Braconi [48], the transparency and clarity of roles and responsibilities are principles underlying corporate governance. These aspects should guide the activities of business organizations in the process of growth and value creation for shareholders and other stakeholders. In addition to the model of corporate governance, a well-defined corporate executive structure is an important aspect for risk management and for the implementation of business strategies.

Table 3 summarizes corporate governance practices identified in the reports of the three companies studied obtained during the documentary analysis stage. 
Table 3. Corporate Governance Practices.

\begin{tabular}{|c|c|c|}
\hline $\begin{array}{l}\text { Study } \\
\text { subjects }\end{array}$ & $\begin{array}{c}\text { Business Practices (reported in the } \\
\text { Sustainability Report) }\end{array}$ & $\begin{array}{l}\text { Munilla and Miles (2005): } \\
\text { Motivators for Sustainability }\end{array}$ \\
\hline$\sum_{0}^{\infty}$ & $\begin{array}{l}\text { The report cites the existence of a board of } \\
\text { directors. }\end{array}$ & $\begin{array}{l}\text { There is no evidence regarding the composition of the } \\
\text { board or the decisions inspired by sustainability. } \\
\text { Note: } \\
\text { According to Munilla and Miles [12], their motivation } \\
\text { for sustainability is by "mere compliance" or "social } \\
\text { pressure". Barin [19] evaluates the reports and } \\
\text { evidence of the motivation for corporate sustainability } \\
\text { according to two types of propositions: conceptual and } \\
\text { operational. }\end{array}$ \\
\hline$\sum_{0}^{\infty}$ & $\begin{array}{l}\text { Board of directors is composed of a president } \\
\text { and three vice-presidents. Company B manages } \\
\text { the business divisions by four advisory } \\
\text { committees: Corporate, HR, Executive and } \\
\text { Financial Audit. There is a Sustainability } \\
\text { Committee composed of the same members of } \\
\text { the board's Executive Committee that discusses } \\
\text { strategies, goals and assessment indicators for } \\
\text { sustainability. }\end{array}$ & $\begin{array}{l}\text { The Board of Directors is detailed in its structure and } \\
\text { there is a report of the Sustainability Committee's } \\
\text { existence. According to Munilla and Miles [12], } \\
\text { Company B's motivation for sustainability can be } \\
\text { classified as strategic. }\end{array}$ \\
\hline${ }_{0}^{u}$ & $\begin{array}{l}\text { The board of directors is composed of three } \\
\text { representatives from each partner company. All } \\
\text { shareholders have a position on the council. No } \\
\text { member of the board of directors performs } \\
\text { executive functions. }\end{array}$ & $\begin{array}{l}\text { The board is detailed regarding its composition. } \\
\text { However, no mention is made regarding actions or } \\
\text { decisions for organizational sustainability. According } \\
\text { to Munilla and Miles [12], the motivation for } \\
\text { sustainability for Company C is by "mere compliance" } \\
\text { or "social pressure". }\end{array}$ \\
\hline
\end{tabular}

The governance structures in the three companies do not resemble each other. The existence of a board of directors seems to be common among the companies. In Company B, a Sustainability Committee was formed to maintain the harmony of the business strategies and to maintain the identity of actions in all subsidiary companies. This committee mobilizes, educates and disseminates sustainability practices for all of the companies to ensure that they all incorporate indicators and social and environmental goals in the company's everyday activities.

In Company $\mathrm{C}$, no actions promoting sustainability-oriented decisions were identified, and Company C appears to obey "green" demands only according to regulations or social pressures. Company A did not have a nucleus for decision-making regarding sustainable practices but has adopted sustainability practices only when social and regulatory pressures are exerted on the construction industry to improve their "green" credentials.

\subsection{Conceptual Matrices Dimension}

The business approach used to create long-term value for shareholders and other stakeholders presupposes discussions about sustainable development and sustainability concepts.

Below, we present the highlights of the sustainability policies found in the reports of the companies studied. For this study, a case analysis methodology was used for the three Brazilian companies. 
The Brazilian construction industry is composed of a large number of small contractors and some larger contractors. For six consecutive years, the companies studied (A, B and C) have remained in the top three rankings of the fifty largest construction companies in Brazil. The total revenue of the companies studied is equivalent to the revenue of the 15 next largest companies in the ranking. Therefore, the economic, social and environmental representation of the three companies analyzed in the Brazilian construction market is significant for this study.

Thus, we have three study samples, companies A, B and C. Through content analysis of the corporate sustainability reports disclosed by the studied companies, all three companies show a sustainability policy, which is described below:

Company A cites in its sustainability report that sustainable development is part of its genesis and is present in the actions of those who make up the organization. The company leadership understands that their actions contribute to the following:

- Economic development, as the company generates results for clients, shareholders and the communities where they operate

- Social development, as the company creates job opportunities and income for the population

- Environmental preservation, as the company makes rational use of natural resources utilizing clean technologies and seeking to reduce waste and mitigate the impacts caused by its operations

- Cultural diversity, as the organization encourages the integration of people from diverse backgrounds, ethnicities, sexual and religious orientations while respecting various customs

- Political participation, as the company actively contributes to the formulation of public policies aimed at promoting sustainable development

Company A is part of the group of Brazilian companies that signed the "Open Letter to Brazil" commitment, by which Company A commits to carry out an inventory of its emissions and implement procedures that will lead to reduced emissions of greenhouse gases.

According to Munilla and Miles [12], the motivation for sustainability in this case was by "mere compliance" or by "social pressure". The sustainability report does not show evidence of practices or action plans that demonstrate an effective engagement with corporate sustainability.

Barin [19] evaluates the reports and evidence to diagnose motivation for corporate sustainability according to two types of propositions: conceptual and operational. With respect to operational propositions, the organization studied shows no evidence of governance integrated with sustainable development.

Company B, is part of the group of Brazilian companies that signed the "Open Letter to Brazil" commitment, by which it commits to carry out an inventory of its emissions and implement procedures that will lead to reduced emissions of greenhouse gases.

Company B works internally with a "climate agenda", where it lists commitments to guide the reduction and mitigation of greenhouse gas (GHG) emissions. Company B evaluates the level of incorporation of sustainability in business practices and in the decision-making models through a methodology it developed called the "sustainability radar".

The "radar" is the result of a questionnaire based on indicators from the Corporate Sustainability Index (Índice de Sustentabilidade Empresarial - ISE) from the Ethos Institute and the Exame Magazine Sustainability Guide. This method assumes the following company priorities regarding the 
sustainability process: safety, programs for suppliers and customers, continuing education in sustainability for the workforce and inclusion of people with disabilities and apprentices.

The company lists and quantifies the risks, which allows the establishment of prevention systems, the evaluation of the means to mitigate these systems and the establishment of contingency plans whether for environmental, social, or economic impacts or for impacts inherent to the construction process. Company B conducts the Partnerships for Sustainability program as a way to empower energy suppliers to meet the environmental requirements set by the company.

According to Munilla and Miles [12], the motivation for sustainability is strategic in this case. There is evidence in the sustainability report of an action plan that is structured with indicators for monitoring.

Company C is part of the group of Brazilian companies that signed the "Open Letter to Brazil" commitment, by which it commits to carry out an inventory of its emissions and implement procedures that will lead to reduced emissions of greenhouse gases. The company quantifies its GHG emissions according to internationally accepted methodologies such as the GHG Protocol, ISO (International Organization for Standardization) 14064 and the IPCC (Intergovernmental Panel on Climate Change) Guidelines.

Company $\mathrm{C}$ manages risks related to social responsibility regarding its supply chain, to avoid situations where the company may be responsible for violations of human rights including child labor, forced or compulsory labor, discrimination, threats to freedom of association, inadequate health and safety conditions, disciplinary practices, unfair pay and illegal working hours. Particularly the health and safety are the most important aspects to the building occupants.

Ho [49] pointed out some characteristics that a healthy building should have: (1) Its window design and layout should facilitate natural ventilation and diffusion of daylight; (2) Its environmental conditions should be clean and hygienic; (3) It should be isolated from noise and air pollution sources; (4) A healthy building should not be too densely populated; and (5) Its water supply and waste systems should be appropriately installed, maintained, and managed.

Ho [49] defined a safe building as one that minimizes the risk of physical injury and the death of occupants, such as evacuating them effectively should emergencies arise.

Company $\mathrm{C}$ monitors the indicators for reducing consumption of natural resources in the environmental management system to account for the use of electric energy, water and fuel. This company adopts internal procedures for water consumption to eliminate potential sources of waste. In addition to treatment, disposal and management of liquid effluents, construction by Company $\mathrm{C}$ seeks to identify opportunities to prevent or reduce the production of wastewater of any kind.

According to Munilla and Miles [12] the motivation for sustainability for Company $\mathrm{C}$ as identified by the measures in the organization's report is strategic. The report does not state policies for sustainability in the field of governance. According to the proposed diagnostic for sustainability motivation, Barin [19] notes that the organization studied shows no evidence of governance integrated with sustainable development. 


\section{Results}

This section displays the results of the analysis of the sustainability reports. Researcher notes were organized into categories and dimensions (Table 2) to search for patterns, regularities, differences and contradictions that would allow for an accurate analysis of the data.

By incorporating a sustainability approach, a company reaffirms its commitment to a sustainable development strategy and takes on a challenge that goes beyond its operations positioning itself as an agent of change in response to new business standards and contributing to the balanced, long-term increase of social, environmental and economic development.

The three companies studied are signatories of the "Open Letter to Brazil on Climate Change" commitment. The commitment is a private sector initiative, which has the support of the Sustainable Amazon Forum and the Ethos Institute. Signatories commit to carry out inventories of greenhouse gas emissions and create mechanisms within their organizations to guide the development of a low-carbon economy.

Commitment to the "Open Letter to Brazil on Climate Change" is a declaration of intent towards sustainability and one that demands material evidence to consolidate organizational sustainable management. Company B utilizes the "sustainability radar", which is used to monitor the effectiveness of the implementation of sustainability in business operations. Actions integrated with business strategy are not identified among the actions listed in company B's sustainability report.

\section{Human Resource Management}

The sustainable management of an organization must disclose its ongoing commitment to improving the quality of life of workers, their families and the local community. Employee competence, involvement and commitment are critical to the good performance and productivity of organizations [50].

The policies and practices of human resource management in the organizations studied are highlighted below. Aspects related to human resource training and development are identified.

Company A understands that one of the main responsibilities of their leaders regarding business practices is to educate through work, which means devoting time and attention to their charges and providing opportunities for the expansion and improvement of knowledge and skills.

Teams are encouraged to exercise increasing productivity, creativity and reuse of knowledge generated within their work experiences. Every year, the company awards the Prize of Distinction, which encourages all creative initiatives, consolidates the culture of keeping records and disseminates knowledge. In 2009, 65,900 company employees attended the main human resource development programs.

The Strategic Programs are aimed at improving the skills of strategic members and expanding interdisciplinary knowledge. In 2012, 2494 employees attended the main programs.

According to Munilla and Miles [12], the motivation for sustainability in this case is "mere compliance" or "social pressure". There is no evidence of practices or action plans in the sustainability report that demonstrate effective engagement with sustainability as a business strategy.

Company B provided 510,648 training hours in 2009 for 38,028 employees, which amounts to an average of 13.43 hours per employee. The program for training and continued learning totaled 
3692 hours of technical training for 162 operational professionals. In addition, the leadership development program totaled another 1584 hours.

In 2009, the Young Professionals Program took place, wherein 37 students completed the graduate program in Engineering and Construction Project Management. A total of $80 \%$ of the classes were taught by professionals from the company, and $20 \%$ of the classes were taught by professors from the affiliated university. To provide support for the program, managers are prepared to monitor the early-stage professionals during their first 15 months in the company.

In Company $\mathrm{C}$, the Balanced Score Card and the Training Index are used to determine whether the construction projects are effectively developing their personnel. The company goal is a number of training hours equal to or greater than $3 \%$ of the hours worked on construction projects with the value accumulated by the superintendence, the board of directors and the corporation. Monitoring is performed during monthly Balanced Score Card meetings during the construction projects, the executive board meetings and the presidency meetings.

Regarding internal recruitment, Company C has evolved by implementing the "Trilhas" ["Pathways"] program, which identifies qualified employees with opportunities for advancement in different areas and businesses.

For the executive functions, the Directorate of Human Resource Development identifies, in conjunction with the presidency and the boards of directors, the core competencies for the organization regardless of the area that are seen as vital for the company to achieve the expected results. Personal and professional targets are identified and an Individual Development Plan (IDP) is established. At the end of each year, professionals are evaluated according to the performance and targets of the previous year, which were forecasted in the Balanced Score Card:

- Using interviews, key employees at the operating level of construction jobs (field managers, supervisors and technicians) are identified, and with the support of superintendents and managers, a customized training plan is developed. Tutors are chosen that will be responsible for their development.

- The company invested in training new generations arriving into the labor market. Through the internship program, the company is training young people to take on challenges with the necessary skills to work for the company in the future. In turn, the managers are trained to manage and train these interns.

According to Barin [19], analysis of the conceptual propositions shows no evidence of a corporate governance focus on business ethics and organizational learning. Studying the organizational report, one can identify, according to operational propositions, that the human resource management policy places no priority on business ethics, human rights policy in the organization or policies of respect for diversity and gender equality. No evidence could be found regarding policies for knowledge management or for creating mechanisms for organizational learning, awareness and information sharing on sustainable development.

According to Relvas [51], organizational learning is an important theme in organizational studies. The generation and use of knowledge in organizations is a strategic factor for competitiveness and innovation. Organizational learning creates opportunities to develop skills for creative innovation. To come up with strategies for collective learning is part of the concept of contemporary competition. The 
challenge is to transform individual knowledge into collective learning. According to Barbieri, Freitas, Andreassi and Carvalho [52], some factors intervene with the interactivity of sustainability with innovation and knowledge sharing. When addressing business competitiveness, according to Tidd, Bessant and Pavitt [53], policies on sustainability, innovation and organizational learning must be defined and valued by organizational governance.

According to Barbieri, Freitas, Andreassi and Carvalho [52], the organization model is an innovative sustainable response to institutional pressures by an organization that is able to innovate effectively in economic terms, but social and environmental responsibility. This type of organization is seeking competitive advantage by developing products, services, and business processes, new or modified based on social, environmental and economic. She meets two essential characteristics: it is innovative and oriented towards sustainability. So there is a new logic of production in which sustainability and innovation go together.

Based on the results displayed by companies A, B and C, the companies show evidence of adopting the traditional "Training and Development" approach based on a reductionist pedagogical concept primarily serving the immediate and economic interests (short-term courses).

Collins and Porras [54] present the idea that, to perpetuate itself in the market, a company needs to develop a sense of common purpose among employees and a set of core values to guide behaviors within the organization. This is a role that must be assumed by the managers of corporate education structures in business organizations committed to sustainability in the social dimension.

The analysis presented indicates that Company $\mathrm{C}$ incorporates modern strategies for human resource management based on models of competence management, where the starting point is the clear definition of the skills profile required in the business areas of Company $\mathrm{C}$.

Regarding the education of professionals working with the sustainable development of construction, sustainability will be systematically incorporated into their curriculum for the benefit of trained professionals, companies and educators [55].

\section{Conclusions and Suggestions for Future Studies}

The sustainability reports of the companies analyzed declare that the aspects related to the integration of social, political and economic development was the driver for sustainable business models in the heavy construction sector. Generally, the motivations of the three companies originate in the competitive environment arising from changes in production standards, economic globalization, contractor demands and environmental laws.

There is evidence that the three companies studied adopted actions, policies and conceptual and operational guidelines in their business models that are beyond their legal obligations. The three companies signed the "Open Letter to Brazil on Climate Change". This action assumes a commitment to corporate social responsibility as a guideline for business influencing the management in the production chain.

Regarding human resource development, the companies practice the traditional model of Training and Development based on a concept that caters primarily to economic and immediate interests (short-term programs focused on completing routine tasks and procedures).

The companies have sought to set forth the goals of profit making and remuneration of shareholders adopting management models without integrating business strategy and a commitment to 
sustainability. This study highlights the need to adopt a critical stance in relation to the current economic, political and institutional dynamics with the purpose of questioning the discourse. This study did not intend to change the social structure, but to promote sustainability as a new element that can be easily integrated within contemporary management practices.

Discourse in favor of sustainability is unanimous. However, the measures necessary to transform decision-making models have not been adopted in the business practices. Current decision-making models continue to prioritize economic factors at the expense of social and environmental aspects. Cases reported in the literature have identified superficial transformations and increases in legal restrictions that are not effective.

There is a need to assess the social, economic and environmental dynamics, establish a critical stance towards these aspects, negotiate conflicts of interest and finally, transform the criteria for decision-making to be able to identify genuine efforts towards corporate sustainability. In the business field, practical sustainability actions occur in an incipient and initial manner. Sustainability actions exist far more in the discourses and official documents of organizations than in their management and decision-making models.

As a suggestion for further studies, we propose performing studies with a similar structure on an annual basis to monitor the evolution of management technology in Brazilian heavy construction companies. These Brazilian multinational companies are important in the national economic scenario and deserve detailed attention and monitoring.

\section{Conflicts of Interest}

The authors declare no conflict of interest.

\section{References}

1. Afonso, C.M. Sustentabilidade: Caminho ou Utopia (in Portuguese)? Annablume: São Paulo, Brazil, 2006.

2. Siche, R.; Agostinho, F.; Ortega, E.; Romeiro, A. Índices versus indicadores: precisões conceituais na discussão da sustentabilidade de países. Ambiente \& Sociedade, 2007, X, 137-148, (in Portuguese).

3. Deluiz, N.; Novicki, V. Trabalho, Meio Ambiente e Desenvolvimento Sustentável: Implicações Para Uma Proposta de Formação Crítica. Available online: http://www.senac.br/BTS/ 302/boltec302b.htm (accessed on 12 September 2013), (in Portuguese).

4. Lima, G.D.C. O discurso da sustentabilidade e suas implicações para a educação. Available online: http://www.scielo.br/scielo.php?script=sci_arttext\&pid=S1414-753X2003000300007\&lng= pt\&nrm=iso\&tlng=pt (accessed on 12 September 2013), (in Portugues).

5. Layrargues, P.P. Do ecodesenvolvimento ao desenvolvimento sustentável: Evolução de um conceito? 1997, Revista Proposta, 71, 5-10, (in Portuguese).

6. Chesnais, F. A Mundialização do Capital (in Portuguese); Xamã Editora: São Paulo, Brazil, 1996.

7. Sachs, I. Eco Desenvolvimento: Crescer Sem Destruir (in Portuguese); Vértice: São Paulo, Brazil, 1986. 
8. Gollagher, M.; Hartz-Karp, J. The role of deliberative collaborative governance in achieving sustainable cities. Sustainability 2013, 5, 2343-2366.

9. Arruda, L.; Quelhas, O.L.G. Sustentabilidade: um longo processo histórico de reavaliação crítica da relação existente entre a sociedade e o meio ambiente. Available online: http://www.senac.br/ BTS/363/artigo6.pdf (accessed on 4 July 2013), (in Portuguese).

10. WCED-World Commission on Environment and Development. Our Common Future; Oxford University Press: Oxford, UK, 1987.

11. Sachs, I. Rumo à Ecossocioeconomia: Teoria e Prática do Desenvolvimento (in Portuguese); Cortez: São Paulo, Brazil, 2007.

12. Munilla, L.S.; Miles, M.P. The corporate social responsibility continuum as a component of stakeholder theory. Bus. Soc. Rev. 2005, 110, 371-387.

13. Miles, M.P.; Covin, J.G. Environmental marketing: A source of reputational, competitive, and financial advantage. J. Bus. Ethics 2000, 23, 299-311.

14. Miles, M.P.; Munilla, L.S.; Covin, J.G. The constant gardener revisited: The effect of social blackmail on the marketing concept, innovation, and entrepreneurship. J. Bus. Ethics 2002, 41, 287-295.

15. Porter, M.E.; Kramer, M.R. Strategy and society: the link between competitive advantage and corporate social responsibility. Harv. Bus. Rev. 2006, 84, 78-92.

16. Cheibub, Z.; Locke, R. Valores ou Interesses? Reflexões Sobre a Responsabilidade Social das Empresas (in Portuguese). Availabe online: http://rlocke.scripts.mit.edu/ rlocke/docs/papers/ Locke,R\%20\%26\%20Cheibub,Z_Valores\%20ou\%20Interesses.pdf (accessed on 8 July 2013).

17. Druker, P. Tecnology, Management, and Society. Available online: http://www.wissens navigator.ch/documents/taylorscientificmanagement.pdf (accessed on 6 July 2013).

18. Taylor, F.W. The Principles of Scientific Management; Harper \& Brothers Publishers: New York, NY, USA, London, UK, 2011.

19. Barin Cruz, L. Processo de Formação de Estratégias de Desenvolvimento Sustentável de Grupos Multinacionais (in Portugues). Ph.D. Theis, Escola de Administração, UFRGS Universidade Federal do Rio Grande do Sul, Porto Alegre, Brazil, 2007.

20. Dyllick, T.; Hockerts, K. Beyond the Business Case for Corporate Sustainability. Bus. Strat. Environ. 2002, 11, 130-141.

21. Elkington, J. Partnerships from cannibals with forks: The triple bottom line of 21 st-century business. Environ. Qual. Manag. 1998, 8, 37-51.

22. Van der Heijden, J.; de Jong, J. Towards a better understanding of building regulation. Environ. Plann. Plann. Des. 2009, 36, 1038-1052.

23. Wheeler, S.M.; Beatley, T. The Sustainable Urban Development Reader, 2 nd ed.; Routledge: London, UK, 2009.

24. Pernick, R.; Wilder, C. The Clean Tech Revolution: The Next Big Growth and Investment Opportunity; HarperCollins: New York, NY, USA, 2007.

25. Toole, T.M. Uncertainty and home builders' adoption of technological innovations. J. Construct. Eng. Manag. 1998, 124, 323-332.

26. Kolk, A.; Pinkse, J. Stakeholder mismanagement and corporate social responsibility crises. Eur. Manag. J. 2006, 24, 59-72. 
27. Beerepoot, M.; Beerepoot, N. Government regulation as an impetus for innovation: Evidence from energy performance regulation in the Dutch residential building sector. Energ. Pol. 2007, $35,4812-4825$.

28. Lützkendorf, T.; Lorenz, D. Green Buildings-Just Environmentally Sound or Also Economical and a Stable Investment? Association of German Pfandbrief Banks: Berlin, Germany, 2008.

29. Corps, C. Toward Sustainable Financing and Strong Markets for Green Building: Valuing Sustainability. Available online: http://www3.cec.org/islandora/en/item/2329-paper-2c-towardsustainable-financing-and-strong-markets-green-buildingvaluing (accessed on 15 July 2013).

30. Pivo, G. Owner-Tenant Engagement in Sustainable Property Investing. J. Sustain. Real Estate 2010, 2, 184-199.

31. Ellison, L.; Sayce, S. The Sustainable Property Appraisal Project; Kingston University: Surrey, UK, 2006.

32. Kizilaslan, N.; Grler, A.Z.; Kizilaslan, H. An Analytical Approach to Sustainable Development in Turkey. Sustain. Dev. 2007, 15, 254-266.

33. GRI-G3. Disponível em. Available online: http:/www3.ethos.org.br/conteudo/iniciativas/ indicadores/\#.Uki9Joakorl (accessed on 14 July 2013), (in Portuguese).

34. Krischke, P.J. The Learning of Democracy in Latin America: Social Actors and Cultural Change; Nova Science Pub Incorporated: Nova York, Brazil, 2001.

35. Fundação Brasileira para o Desenvolvimento Sustentável (FBDS). Available online: http://fbds.org.br/fbds/article.php3?id_article=247 (accessed on 14 July 2013), (in Portuguese).

36. Programa das Nações Unidas para o Meio Ambiente. Available online: http://www.onu.org.br/onu-no-brasil/pnuma/ (accessed on 14 July 2013), (in Portuguese).

37. Nações Unidas no Brasil. Available online: http://www.onu-brasil.org.br/ (accessed on 14 July 2013), (in Portuguese).

38. Quelhas, O.L.G; Aride, S.S. Gestão de pessoas: Perspectivas da sustentabilidade humana. Available online: http://www1.sp.senac.br/hotsites/arquivos_materias/II_workshop/Gestao_de_ pessoas_perspectivas_da_sustentabilidade_humana.pdf (accessed on 18 July 2013).

39. Milkovich, G.; Boudreau, J. Administração de Recursos Humanos (in Portugues); Atlas: São Paulo, Brazil, 2000.

40. Calia, C.R. A difusão da produção mais limpa: o impacto do seis sigma no desempenho ambiental sob o recorte analítico de redes. Available online: http:/www.teses.usp.br/teses/disponiveis/ 18/18140/tde-31072007-153120/pt-br.php (accessed on 20 July 2013), (in Portugues).

41. Dupas, G. Pobreza, desigualdad y trabajo en el capitalism. Available online: http://www.nuso.org/upload/articulos/3522_1.pdf (accessed on 20 July 2013), (in Spanish).

42. Deluiz, N. A globalização econômica e os desafios à formação professional. Availble online: http://www.senac.br/BTS/303/boltec303f.htm (accessed on 20 July 2013), (in Portugues).

43. Valle, R. O Conhecimento em Ação: Novas Competências Para o Trabalho no Contexto Da Reestruturação Produtiva (in Portugues); Relume-Dumará: Rio de Janeiro, Brazil, 2003.

44. Antunes, M.T.P.; Martins, E. Capital intelectual: Verdades e mitos. Rev. Contab. Finanç. 2002, 13, 41-54, (in Portugues).

45. Meister, J.C. Educação Corporativa: A Gestão do Capital Intelectual Através das Universidades Corporativas (in Portugues); Makron Books: São Paulo, Brasil, 1999. 
46. Garrido, P.O. Educação Corporativa Policêntrica: Aplicação Transdisciplinar da Engenharia Pedagógica para a Produção da Aprendizagem Transformadora (in Portugues); Tese de Doutorado: Florianópolis, Brazil, 2006.

47. Teixeira, E.B. Educação Continuada Corporativa: Aprendizagem e Desenvolvimento Humano No Setor Metal-Mecânico (in Portugues); UFSC: Tese de Doutorado, Brazil, 2005.

48. Braconi, J. O Conceito De Governança Como Contribuição À Análise Das Transformações Organizacionais (in Portugues). Ph.D. Dissertation, UFRJ/COPPE, Rio de Janeiro, Brazil, 2010.

49. Ho, D.C.W.; Leung, H.F.; Wong, S.K.; Cheung, A.K.C.; Lau, S.S.Y.; Wong, W.S. Assessing the health and hygiene performance of apartment buildings. Facilities 2004, doi: $10.1108 / 02632770410527789$.

50. Tachizawa, T.; Ferreira, V.C.P.; Fortuna, A.A.M. Gestão Com Pessoas (in Portugues); FGV Editora: Rio de Janeiro, Brasil, 2001.

51. Relvas, M. O Processo de Aprendizagem Organizacional: Perspectiva do Poder Judiciário (in Portugues). Ph.D. Dissertation, Escola Brasileira de Administração Pública e de Empresas da Fundação Getúlio Vargas do Rio de Janeiro (EBAPE), Rio de Janeiro, Brazil, 2012.

52. Barbieri, J.C.; Vasconcelos, I.F.G.; Andreassi, T.; Carvalho de Vasconcelos, F. Inovação e Sustentabilidade: Novos Modelos e Proposições. Rev. Adm. Empresas. 2010, 50, 146-154, (in Portuguese).

53. Tidd, J.; Bessant, J.; Pavitt, K. Managing Innovation: Integrating Technological, Market and Organizational Change, 3 rd ed.; John Wiley \& Sons: London, UK, 2005.

54. Collins, J.C.; Porras, J.I. Feitas Para Durar (in Portugues); 6 th ed.; Editora Rocco: Rio de Janeiro, Brazil, 1998.

55. Murray, P.E.; Cotgrave, A.J. Sustainability Literacy: The Future Paradigm for Construction Education. Struct. Surv. 2007, 25, 7-23.

(C) 2013 by the authors; licensee MDPI, Basel, Switzerland. This article is an open access article distributed under the terms and conditions of the Creative Commons Attribution license (http://creativecommons.org/licenses/by/3.0/). 